\title{
Kewenangan dan Tanggung Jawab Notaris Pengganti setelah Pelaksanaan Tugas dan Jabatan Berakhir
}

\author{
Tengku Erwinsyahbana \\ Muhammadiyah University of Sumatera Utara, Indonesia \\ tengkuerwins@umsu.ac.id
}

\author{
Melinda \\ Muhammadiyah University of Sumatera Utara, Indonesia \\ melinda_tan_mei@yahoo.com
}

\begin{abstract}
As an honorable position and profession, the notary replacement also has obligations that must be implemented, either based on laws and regulations that specifically regulate notary public, UUJN, or other laws and regulations. The authority of a notary substitute shall be the same as that of a notary public, comprising of general authority, special powers and powers which shall be determined later in accordance with the laws and regulations. The replacement notary's legal liability includes civil liability, criminal responsibility, UUJN-based responsibilities, and responsibility for performing his / her duties under the Notary's Code of Conduct. However, the limitation of the length of time the substitute notary's responsibility to the deeds he made has not been explicitly regulated in the UUJN.
\end{abstract}

KEYWORDS: Deed, Authority, Notary Substitute, Responsibility.

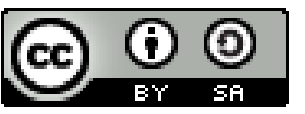

Copyright $\odot 2018$ by Author(s)

This work is licensed under a Creative Commons Attribution-ShareAlike 4.0 International License. All writings published in this journal are personal views of the authors and do not represent the views of this journal and the author's affiliated institutions.

\section{HOW TO CITE:}

Erwinsyahbana, Tengku \& Melinda. "Kewenangan dan Tanggung Jawab Notaris Pengganti setelah Pelaksanaan Tugas dan Jabatan Berakhir" (2018) 5:2 Lentera Hukum 323-340.

Submitted: March 31, 2018 Revised: May 21, 2018 Accepted: June 29, 2018 


\section{PENDAHULUAN}

Kehidupan masyarakat yang berkembang memerlukan kepastian hukum dalam sektor pelayanan jasa. Salah satu pekerjaan yang menawarkan pelayanan jasa dalam bidang hukum, khususnya hukum perdata adalah notaris, yang merupakan pejabat umum dan diangkat oleh pemerintah untuk membantu masyarakat dalam hal membuat perjanjianperjanjian. Perlunya perjanjian-perjanjian tertulis dibuat di hadapan notaris adalah untuk menjamin kepastian hukum, serta memenuhi hukum pembuktian kuat bagi para pihak yang membuat perjanjian. Kebutuhan akan pembuktian tertulis ini yang menghendaki pentingnya lembaga notariat. ${ }^{1}$

Notaris merupakan profesi hukum sehingga profesi ini merupakan profesi mulia (nobile officium). Notaris disebut sebagai pejabat mulia, karena profesi notaris sangat erat hubungannya dengan kemanusiaan. Akta yang dibuat oleh notaris dapat menjadi dasar hukum atas status harta benda, hak dan kewajiban seseorang. Kekeliruan atas akta yang dibuat notaris dapat menyebabkan tercabutnya hak seseorang atau terbebaninya seseorang atas suatu kewajiban. Oleh karena itu, notaris dalam menjalankan tugas jabatannya harus mematuhi berbagai ketentuan yang tersebut dalam Undang-Undang Nomor 30 Tahun 2004 tentang Jabatan Notaris sebagaimana telah diubah dengan Undang-undang Nomor 2 Tahun 2014 tentang Perubahan atas Undang-Undang Nomor 30 tahun 2004 tentang Jabatan Notaris ${ }^{2}$ (UUJN).

Notaris adalah pejabat umum, diangkat dan diberhentikan oleh Menteri Hukum dan Hak Asasi Manusia. Notaris sebagai pejabat umum bertugas untuk memberikan pelayanan kepada anggota masyarakat yang memerlukan jasanya dalam pembuatan alat bukti tertulis, khususnya berupa akta autentik dalam bidang hukum perdata, dan keberadaan notaris merupakan pelaksanaan dari hukum pembuktian. ${ }^{3}$ Melalui akta yang dibuatnya notaris harus dapat memberikan kepastian hukum kepada masyarakat. ${ }^{4}$

UUJN memberikan kewenangan kepada notaris untuk menuangkan semua perbuatan, perjanjian, dan penetapan yang dikehendaki oleh pihak-pihak yang menghadapnya untuk meminta kepada notaris agar keterangannya dituangkan ke dalam suatu akta autentik sehingga mempunyai kekuatan pembuktian yang sempurna. Berdasarkan Pasal 15 ayat (1) UUJN ditentukan bahwa notaris berwenang membuat akta autentik mengenai semua perbuatan, perjanjian, dan penetapan yang diharuskan oleh peraturan perundang-undangan dan/atau yang dikehendaki oleh yang

\footnotetext{
R. Soegondo Notodisoerjo. 1993. Hukum Notariat di Indonesia. Jakarta: Raja Grafindo, hlm. 1-4.

Abdul Ghofur Anshori. 2009. Lembaga Kenotariatan Indonesia, Perspektif Hukum dan Etika, Yogyakarta: UII-Press, hlm. 46.

3 Herlien Budiono. 2013. Kumpulan Tulisan Hukum Perdata di Bidang Kenotariatan Buku Kedua. Bandung: Citra Aditya Bakti, hlm. 220.

4 H. Salim dan H. Abdulah. 2007. Perancang Kontrak dan MOU. Jakarta: Sinar Grafika, hlm. 101102.Berdasarkan Pasal 1 angka 1 Undang-undang Republik Indonesia Nomor 2 Tahun 2014 tentang Perubahan atas Undang undang Nomor 30 tahun 2004 tentang Jabatan Notaris dijelaskan bahwa notaris adalah pejabat umum yang berwenang untuk membuat akta autentik dan memiliki kewenangan lainnya sebagaimana dimaksud dalam undang-undang ini atau berdasarkan undangundang lainnya.
} 
berkepentingan untuk dinyatakan dalam akta autentik, menjamin kepastian tanggal pembuatan akta, menyimpan akta, memberikan grosse, salinan dan kutipan akta. Semuanya itu sepanjang pembuatan akta tidak juga ditugaskan atau dikecualikan kepada pejabat lain atau orang lain yang ditetapkan oleh undang-undang. Selain kewenangan ini, berdasarkan Pasal 15 ayat (2) UUJN ditentukan bahwa notaris juga memiliki kewenangan lain. Pertama, mengesahkan tanda tangan dan menetapkan kepastian tanggal surat di bawah tangan dengan mendaftar dalam buku khusus. Kedua, membukukan surat di bawah tangan dengan mendaftar dalam buku khusus. Ketiga, membuat salinan dari surat asli di bawah tangan berupa salinan yang memuat uraian sebagaimana ditulis dan digambarkan dalam surat yang bersangkutan. Keempat, melakukan pengesahan kecocokan fotokopi dengan surat aslinya. Kelima, memberikan penyuluhan hukum sehubungan dengan pembuatan akta. Keenam, membuat akta yang berkaitan dengan pertanahan. Ketujuh, membuat akta risalah lelang.

Notaris dalam melaksanakan kewajibannya harus sesuai dengan peraturan perundang-undangan yang berlaku, sehingga akta yang dibuat menjadi akta autentik. Kewajiban-kewajiban notaris dalam menjalankan jabatannya diatur pada Pasal 16 UUJN, yaitu bertindak amanah, jujur, seksama, mandiri, tidak berpihak, dan menjaga kepentingan pihak yang terkait dalam perbuatan hukum; membuat akta dalam bentuk minuta akta dan menyimpannya sebagai bagian dari protokol notaris; melekatkan surat dan dokumen serta sidik jari penghadap pada minuta akta; mengeluarkan grosse akta, salinan akta, atau kutipan akta berdasarkan minuta akta; memberikan pelayanan sesuai dengan ketentuan dalam undang-undang ini, kecuali ada alasan untuk menolaknya; merahasiakan segala sesuatu mengenai akta yang dibuatnya dan segala keterangan yang diperoleh guna pembuatan akta sesuai dengan sumpah/ janji jabatan, kecuali undangundang menentukan lain; menjilid akta yang dibuatnya dalam satu bulan menjadi buku yang memuat tidak lebih dari 50 akta, dan jika jumlah akta tidak dapat dimuat dalam satu buku, akta tersebut dapat dijilid menjadi lebih dari satu buku, dan mencatat jumlah minuta akta, bulan, dan tahun pembuatannya pada sampul setiap buku; membuat daftar dari akta protes terhadap tidak dibayar atau tidak diterimanya surat berharga; membuat daftar akta yang berkenaan dengan wasiat menurut urutan waktu pembuatan akta setiap bulan; mengirimkan daftar akta atau daftar nihil yang berkenaan dengan wasiat ke pusat daftar wasiat pada kementerian yang menyelenggarakan urusan pemerintahan di bidang hukum dalam waktu 5 hari pada minggu pertama setiap bulan berikutnya; mencatat dalam repertorium tanggal pengiriman daftar wasiat pada setiap akhir bulan; mempunyai cap atau stempel yang memuat Lambang Negara Republik Indonesia dan pada ruang yang melingkarinya dituliskan nama, jabatan, dan tempat kedudukan yang bersangkutan; membacakan akta di hadapan penghadap dengan dihadiri oleh paling sedikit dua orang saksi, atau empat orang saksi khusus untuk pembuatan akta wasiat di bawah tangan, dan ditandatangani pada saat itu juga oleh penghadap, saksi, dan notaris; serta menerima magang calon notaris. 
Akta yang dibuat oleh notaris sebagai alat bukti, harus memiliki unsur kesempurnaan, baik dari segi materil maupun formil. Dengan demikian, notaris wajib bertanggungjawab atas akta yang telah dibuatnya. Apabila akta yang dibuat tidak seperti ketentuan yang telah diatur dalam undang-undang, maka akta tersebut cacat secara yuridis dan mengakibatkan akta tersebut kehilangan keautentikannya dan batalnya akta tersebut. Cacatnya suatu akta autentik dapat menyebabkan notaris bertanggung gugat dan dapat dikenai sanksi ganti rugi yang telah dialami para pihak.

Akta adalah tulisan yang semata-mata dibuat untuk membuktikan sesuatu hal atau peristiwa, karenanya suatu akta harus selalu ditandatangani. ${ }^{5}$ Menurut Sudikno Mertokusumo, akta adalah surat yang diberi tanda tangan yang memuat peristiwaperistiwa yang menjadi dasar dari suatu hak/perikatan yang dibuat sejak semula dengan sengaja untuk pembuktian. ${ }^{6}$ Sehingga pembuatan akta notaris dapat digunakan sebagai pembuktian dalam sebuah sengketa hukum yang digunakan sebagai alat untuk mengingat kembali peristiwa-peristiwa yang telah terjadi, yang dapat digunakan untuk kepentingan pembuktian. ${ }^{7}$

Dalam praktiknya, notaris dapat menunjuk seorang notaris pengganti yang lazimnya adalah salah satu karyawan yang bekerja di kantornya. Notaris menyerahkan protokol notarisnya kepada notaris pengganti, sehingga dalam penguasaan notaris pengganti terdapat protokol notaris dari nNotaris yang digantikan oleh notaris pengganti dan protokol yang meliputi akta-akta yang dibuatnya sendiri. Adanya pengaturan tentang notaris pengganti bertujuan untuk memenuhi kebutuhan masyarakat dalam pembuatan akta, sebagaimana yang diatur dalam Pasal 15, Pasal 16, Pasal 17 UUJN. Notaris yang menjalankan cuti wajib menyerahkan protokol notaris ${ }^{8}$ kepada notaris pengganti dan protokol tersebut diserahkan kembali kepada notaris setelah cuti berakhir. Serah terima jabatan tersebut dibuatkan berita acara dan disampaikan kepada Majelis Pengawas Wilayah, ${ }^{9}$ dan walaupun cuti notaris telah berakhir dan protokol telah diserahkan kepada notaris, tetapi notaris pengganti tetap bertanggung jawab atas setiap akta yang dibuatnya. ${ }^{10}$

Kedudukan notaris pengganti dianggap untuk menutupi kekosongan jabatan notaris karena notaris tersebut tidak dapat menjalankan kewajiban sementara waktu dengan alasan yang sudah diatur dalam undang-undang. Keberadaan notaris pengganti dalam pembuatan akta tidak ada perbedaan, sehingga akta yang dibuat oleh notaris pengganti memiliki kekuatan hukum yang sama dengan akta yang dibuat notaris yang

R. Subekti. 1996. Pokok-pokok Hukum Perdata. Jakarta: Intermasa, hlm. 178.

Sudikno Mertokusumo. 1998. Hukum Acara Perdata Indonesia. Yogyakarta: Liberty, hlm. 142.

R. Soegondo Notodisoerjo. supra note 1, hlm. 19.

8 Protokol Notaris adalah kumpulan dokumen yang merupakan arsip negara yang harus disimpan dan dipelihara oleh Notaris sesuai dengan ketentuan peraturan perundang-undangan. Lihat Pasal 1 ayat (13) Undang-undang Nomor 2 Tahun 2014 tentang Perubahan atas Undang-undang Nomor 30 tahun 2004 tentang Jabatan Notaris.

9 Lihat Pasal 32 Undang-undang Nomor 2 Tahun 2014 tentang Perubahan atas Undang-undang Nomor 30 tahun 2004 tentang Jabatan Notaris.

10 Lihat Pasal 65 Undang-undang Nomor 2 Tahun 2014 tentang Perubahan atas Undang-undang Nomor 30 tahun 2004 tentang Jabatan Notaris. 
menunjuknya ataupun dengan Notaris lain di seluruh wilayah hukum Negara Indonesia.

Menjadi notaris pengganti bukan semata-mata memiliki tanggung jawab selama menjabat menjadi notaris pengganti, tetapi tanggung jawab itu akan tetap melekat selama akta yang dibuat oleh notaris pengganti tersebut masih dipergunakan dan notaris pengganti tersebut masih hidup, sehingga jabatan notaris pengganti tidak dapat dimanfaatkan sebagai ajang untuk dapat membuat akta sebanyak-banyaknya tanpa memperhatikan aturan hukum, mekanisme, syarat dalam membuat suatu akta. Notaris pengganti tidak ada batasan dalam membuat akta selama masih berada dalam koridor hukum dan tidak bertentangan dengan peraturan perundang-undangan yang dapat merugikan pihak klien, maupun pihak lain yang berhubungan dengan akta yang dibuatnya.

Notaris pengganti dapat saja berbuat kesalahan dalam menjalankan profesinya. Kesalahan dalam menjalankan profesi dapat disebabkan oleh kurangnya pengetahuan atau ketidaktahuan (onvoldoende kennis), kurang pengalaman atau kurangnya jam terbang (onvoldoende ervaring), dan kurang pengertian (onvoldoende inzicht). ${ }^{11}$ Begitu pula dengan kesalahan notaris terkait profesinya sebagai pejabat pembuat akta, biasanya disebabkan oleh minimnya pengetahuan notaris terkait persoalan yang diinginkan oleh para pihak yang menghadap baik dari aspek pengetahuan, aspek hukum maupun dari aspek yang berkaitan dengan keahlian notaris. ${ }^{12}$ Apabila notaris pengganti melakukan kesalahan dalam pembuatan akta, maka dirinya tetap mempunyai kewajiban untuk mempertanggungjawabkan kesalahannya terhadap akta tersebut.

Jenis penilitian yang digunakan dalam permasalahan ini adalah penelitian yuridis normatif, ${ }^{13}$ yakni penelitian yang mengandalkan data hukum yang bersifat sekunder yang sudah tersedia dan dipublikasikan. Penelitian ini menggunakan pendekatan perundang-undangan, berarti aturan hukum merupakan fokus dan sekaligus tema sentral penelitian. ${ }^{14}$ Penelitian ini bersifat deskriptif, ${ }^{15}$ maksudnya untuk memberikan

11 Nico. 2003. Tanggungjawab Notaris Selaku Pejabat Umum. Yogyakarta: Center for Documentation and Studies of Bussines Law, hlm. 98.

12 Husni Thamrin. 201l. Pembuatan Akta Pertanahan oleh Notaris. Yogyakarta: Pressindo, hlm. 92.

13 Penelitian hukum normatif diartikan sebagai penelitian yang meneliti bahan kepustakaan (data sekunder) yang relevan dengan permasalahan yang akan dianalisis, baik berupa bahan hukum primer, bahan hukum sekunder maupun bahan hukum tertier. Lihat Soerjono Soekanto dan Sri Mamudji. 2003. Penelitian Hukum Normatif, Suatu Tinjauan Singkat. Cetakan Keenam. Jakarta: Rada Grafindo Persada, hlm. 14. Lihat juga Ronny Hanitijo Soemitro. 1990. Metode Penelitian Hukum dan Jurimetri. Cetakan Keempat. Jakarta: Ghalia Indonesia, hlm. ll.

14 Menurut Johnny Ibrahim, dikatakan bahwa dalam kaitannya dengan penelitian normatif dapat digunakan beberapa pendekatan, yaitu (a) pendekatan perundang-undangan (statute approach); (b) pendekatan konsep (conceptual approach); (c) pendekatan analitis (analytical approach); (d) pendekatan perbandingan (comparative approach); (e) pendekatan historis (historical approach); (f) pendekatan filsafat (philosophical approach); dan (g) pendekatan kasus (case approach). Lihat Johny Ibrahim. 2006. Teori e Metodologi Penelitian Hukum Normatif. Cetakan Kedua. Malang: Bayumedia Publishing, hlm. 300.

15 Deskriptif berarti bahwa analisis data bersifat deduktif berdasarkan teori atau konsep yang bersifat umum diaplikasikan untuk menjelaskan tentang seperangkat data atau menunjukkan 
keadaan hukum tentang kewenangan dan tanggung jawab notaris pengganti setelah pelaksanaan tugas dan jabatannya berakhir.

Dalam hubungannya dengan proses pengumpulan data dan jika dilihat dari jenisnya, data dibedakan menjadi data primer dan data sekunder. Data primer merupakan data yang diperoleh dari langsung dari objek yang diteliti, sedangkan data sekunder merupakan data dalam bentuk jadi, seperti data dokumen dan publikasi. ${ }^{16}$ Penelitian ini hanya membutuhkan data sekunder yang diperoleh dari dokumen atau publikasi pada perpustakaan dan instansi pemerintahan, baik ilmiah maupun nonilmiah.

Teknik pengumpulan data yang digunakan dalam penelitian adalah dengan teknik studi dokumen. Teknik ini diperlukan untuk mendapatkan data sekunder dari perpustakaan dan instansi pemerintahan, sehingga penelitian ini dilaksanakan dengan mengumpulkan literatur dari dokumen yang terdapat dalam berbagai peraturan perundang-undangan, serta ajaran para sarjana (doktrin). Berhubung paradigma penelitian ini adalah penelitian kualitatif (khususnya dalam bidang hukum), ${ }^{17}$ maka analisis yang dilakukan secara kualitatif atau lebih tepat disebut sebagai analisis yuridis kualitatif. $^{18}$

\section{TEORI KEWENANGAN DAN TANGGUNG JAWAB}

Istilah kewenangan (authority) dan tanggung jawab (responsibility) sering disebut ketika berbicara tugas seseorang dalam pelaksanaan jabatannya, karena wewenang diperoleh dari jabatannya, sedangkan tanggung jawab adalah suatu bentuk kewajiban seseorang melaksanakan fungsi dan tugasnya berdasarkan kewenangan yang dimiliki karena jabatannya. Wewenang dan tanggung jawab dipadankan kedudukannya, karena setiap keputusan yang dikeluarkan oleh pejabat berwenang dapat bersifat mengikat (mandatory) dan pada pemilik kewenangan sekaligus dalam waktu bersamaan melekat sebuah tanggung jawab bahwa hal yang telah diputuskan dapat dijamin keabsahannya secara hukum formal. Pada sisi yang lain dapat pula menjadi acuan bagi pengambilan

komparasi/hubungan seperangkat data dengan seperangkat data lainnya. Lihat Bambang Sunggono. 1998. Metodologi Penelitian Hukum. Cetakan Kedua. Jakarta: Raja Grafindo Persada, hlm. 38.

16 Soerjono Soekanto. 1986. Pengantar Penelitian Hukum, Jakarta: Penerbit Universitas Indonesia, hlm. 57.

17 Metode penelitian kualitatif merupakan metode penelitian yang lebih menekankan pada aspek pemahaman secara mendalam terhadap suatu masalah dari pada melihat permasalahan untuk penelitian generalisasi, yang menggunakan teknik analisis mendalam (in-depth analysis), yaitu mengkaji masalah secara kasus perkasus, karena metodologi kualitatif meyakini bahwa sifat suatu masalah yang satu akan berbeda dengan sifat dari masalah lainnya. Lihat Tengku Erwinsyahbana dan Ramlan. 2017. "Penelitian Kualitatif Bidang Ilmu Hukum dalam Perspektif Filsafat Konstruktivis". Jurnal Borneo Law Review. Volume 1 Issue 1. Juni, hlm 5.

18 Analisis kualitatif lebih tepat disebut analisis yuridis kualitatif, karena yang dianalisis adalah informasi yang didapat dari peraturan perundang-undangan dan karya ilmiah dalam bidang hukum. Lihat Tengku Erwinsyahbana. 2017. "Pertanggungjawaban Yuridis Direksi terhadap Risiko Kerugian Keuangan Daerah pada Badan Usaha Milik Daerah”. Jurnal Ilmu Hukum De Lega Lata. Volume 2 Nomor 1. Januari-Juni, hlm. 188. 
keputusan lebih lanjut oleh pejabat pada level bawah atau sebagai dasar untuk pelaksanaan eksekusi di lapangan.

Kewenangan merupakan hak menggunakan wewenang yang dimiliki seorang pejabat atau institusi menurut ketentuan yang berlaku. Dengan demikian kewenangan juga menyangkut kompetensi tindakan hukum yang dapat dilakukan menurut kaidahkaidah formal. Jadi kewenangan merupakan kekuasaan formal yang dimiliki oleh pejabat atau institusi. Kedudukan kewenangan sangat penting, sehingga Stroink dan Steenbeek sebagaimana dikutip Ridwan H.R., menyebutnya sebagai konsep inti dalam Hukum Tata Negara dan Hukum Administrasi Negara. ${ }^{19}$

Dalam literatur ilmu politik, ilmu pemerintahan, dan ilmu hukum sering ditemukan istilah "kekuasaan", "kewenangan", dan "wewenang". Kekuasaan sering disamakan dengan kewenangan, dan kekuasaan sering dipertukarkan dengan istilah kewenangan, demikian pula sebaliknya. Bahkan kewenangan sering disamakan juga dengan wewenang. Kekuasaan biasanya berbentuk hubungan dalam arti bahwa "ada satu pihak yang memerintah dan pihak lain yang diperintah" (the rule and the ruled). ${ }^{20} \mathrm{Ada}$ dua jenis kekuasan, yaitu kekuasaan yang tidak berkaitan dengan hukum, yang menurut Maarseven disebut sebagai "blote match", ${ }^{21}$ dan kekuasaan yang berkaitan dengan hukum yang menurut Weber disebut sebagai "wewenang rasional" atau "legal", yakni wewenang yang berdasarkan atas suatu sistem hukum ini dipahami sebagai kaidah-kaidah yang telah diakui serta dipatuhi oleh masyarakat dan bahkan yang diperkuat oleh negara. ${ }^{22}$

Wewenang berkaitan dengan kekuasaan, dan kekuasaan merupakan unsur esensial dari suatu negara dalam proses penyelenggaraan pemerintahan selain unsurunsur lainnya, seperti hukum, kewenangan (wewenang), keadilan, kejujuran, kebijakbestarian, kebajikan. ${ }^{23}$ Kekuasaan merupakan inti dari penyelenggaraan negara, sehingga negara dalam keadaan bergerak (de staat in beweging), dapat berkiprah, bekerja, berkapasitas, berprestasi, dan berkinerja melayani warganya. Oleh karena itu, negara harus diberi kekuasaan, yang menurut Budiardjo adalah kemampuan seseorang atau sekelompok orang untuk mempengaruhi tingkah laku seseorang atau kelompok lain sedemikian rupa, sehingga tingkah laku itu sesuai dengan keinginan dan tujuan dari orang atau negara. ${ }^{24}$

Kekuasaan mempunyai dua aspek, yaitu aspek politik dan aspek hukum, sedangkan kewenangan hanya beraspek hukum. Artinya, kekuasaan itu dapat bersumber dari konstitusi, juga dapat bersumber dari luar konstitusi

19 Ridwan H.R. 2013. Hukum Administrasi Negara. Jakarta: Raja Grafindo Persada, hlm. 99.

20 Miriam Budiardjo. 1998. Dasar-dasar Ilmu Politik. Jakarta: Gramedia Pustaka Utama, hlm. 35-36.

21 Suwoto Mulyosudarmo. 1990. Kekuasaan dan Tanggung Jawab Presiden Republik Indonesia, Suatu Penelitian Segi-segi Teoritik dan Yuridis Pertanggungjawaban Kekuasaan. Surabaya: Universitas Airlangga, hlm. 30.

22 A. Gunawan Setiardja. 1990. Dialektika Hukum dan Moral dalam Pembangunan Masyarakat Indonesia. Yogyakarta: Kanisius, hlm. 52.

23 Rusadi Kantaprawira. 1998. Hukum dan Kekuasaan. Yogyakarta: Universitas Islam Indonesia, hlm. 37-38.

24 Miriam Budiardjo. supra note 20, hlm. 35. 
(inkonstitusional), misalnya melalui kudeta atau perang, sedangkan kewenangan jelas bersumber dari konstitusi. Kewenangan sering disejajarkan dengan istilah wewenang. Istilah wewenang digunakan dalam bentuk kata benda dan sering disejajarkan dengan istilah "bevoegheid" dalam istilah hukum Belanda.

Syafrudin berpendapat bahwa ada perbedaan antara kewenangan (authority, gezag) dengan wewenang (competence, bevoegheid). Kewenangan disebut sebagai kekuasaan formal, kekuasaan yang berasal dari kekuasaan yang diberikan oleh undangundang, sedangkan wewenang hanya mengenai suatu "onderdeel" (bagian) tertentu saja dari kewenangan. Di dalam kewenangan terdapat wewenang-wewenang (rechtsbe voegdheden). Wewenang merupakan lingkup tindakan hukum publik, lingkup wewenang pemerintahan, tidak hanya meliputi wewenang membuat keputusan pemerintah (bestuur), tetapi meliputi wewenang dalam rangka pelaksanaan tugas, dan memberikan wewenang serta distribusi wewenang utama ditetapkan dalam peraturan perundang-undangan. ${ }^{25}$ Secara yuridis, pengertian wewenang adalah kemampuan yang diberikan oleh peraturan perundang-undangan untuk menimbulkan akibat-akibat hukum. $^{26}$

Kewenangan harus dilandasi oleh konstitusi, sehingga kewenangan tersebut merupakan kewenangan yang sah. Dengan demikian, pejabat (organ) dalam mengeluarkan keputusan didukung oleh sumber kewenangan tersebut. Stroink sebagaimana dikutip Abdul Rasyid Thalib, menjelaskan bahwa sumber kewenangan dapat diperoleh bagi pejabat atau institusi pemerintahan dengan cara atribusi, delegasi dan mandat. Kewenangan institusi pemerintah adalah suatu kewenangan yang dikuatkan oleh hukum positif guna mengatur dan mempertahankannya. Tanpa kewenangan tidak dapat dikeluarkan suatu keputusan yuridis yang benar. ${ }^{27}$

Atribusi atau attributie mengandung arti pembagian, yang digambarkan sebagai pemberian kewenangan kepada suatu organ lain yang menjalankan kewenangan itu atas nama dan menurut pendapatnya sendiri tanpa ditunjuk untuk menjalankan kewenangannya itu. Atribusi kewenangan terjadi apabila pendelegasian kekuasaan itu didasarkan pada amanat suatu konstitusi dan dituangkan dalam suatu peraturan pemerintah tetapi tidak didahului oleh suatu pasal untuk diatur lebih lanjut. ${ }^{28}$ Menurut Wijk sebagaimana dikutip Aggussalim, dikatakan bahwa kekuasaan atau kewenangan pemerintah bersumber dari originale legislator yang diartikan sebagai kekuasaan atau kewenangan yang bersumber dari pembuat undang-undang asli dan delegated legislator yang diartikan sebagai pemberi dan pelimpahan kekuasaan atau kewenangan dari

25 Ateng Syafrudin. 2000. "Menuju Penyelenggaraan Pemerintahan Negara yang Bersih dan Bertanggung jawab". Jurnal Pro Justisia. Edisi IV. Bandung: Universitas Parahyangan, hlm. 22.

26 Indroharto dalam Paulus Efendie Lotulung. 1994. Himpunan Makalah Asas-asas Umum Pemerintahan yang Baik. Bandung: Citra Aditya Bakti, hlm. 65.

27 F.A.M. Stroink dalam Abdul Rasyid Thalib. 2006. Wewenang Mahkamah Konstitusi dan Aplikasinya dalam Sistem Ketatanegaraan Republik Indonesia. Bandung: Citra Aditya Bakti, hlm. 219.

28 Agussalim. 2007. Pemerintahan Daerah Kajian Politik dan Hukum. Bogor: Ghalia Indonesia, hlm. 102. 
suatu organ pemerintahan kepada pihak lain untuk mengambil keputusan atas tanggung jawab sendiri. ${ }^{29}$

Kewenangan dalam bentuk delegasi mengandung arti penyerahan wewenang dari pejabat yang lebih tinggi kepada yang lebih rendah. Penyerahan ini tidak dapat dilakukan tanpa adanya kekuatan hukum seperti undang-undang atau peraturan hukum lainnya. Dengan adanya delegasi, maka ada penyerahan wewenang dari pejabat pemerintahan yang satu ke pejabat yang lainnya yang lebih rendah kedudukannya. Dalam delegasi selalu dituntut adanya dasar hukum pemberian delegasi karena untuk menarik kembali delegasi yang telah didelegasikan juga diperlukan peraturan perundang-undangan yang sama seperti pemberian delegasi itu ada. Delegasi adalah penyerahan kewenangan oleh organ yang hingga saat itu ditunjuk untuk menjalankannya kepada satu organ lain yang sejak saat itu menjalankan kewenangan yang didelegasikan atas namanya dan menurut pendapatnya sendiri. ${ }^{30}$

Kewenangan dalam bentuk mandat dapat berupa suruhan (opdracht ) pada suatu organ untuk melaksanakan kompetensinya sendiri maupun tindakan hukum oleh pemegang suatu wewenang memberikan kuasa penuh (volmacht) kepada subjek lain untuk melaksanakan kompetensi nama si pemberi mandat, sehingga penerima mandat bertindak atas nama orang lain. ${ }^{3 l}$ Dalam kewenangan berupa mandat, tidak ada penciptaan atau penyerahan wewenang. Ciri pokok mandat adalah suatu bentuk perwakilan. Mandataris berbuat atas nama yang diwakili, dan pemberi mandat tetap berwenang untuk menangani sendiri wewenangnya jika diinginkannya. Pemberi mandat juga dapat memberi segala petunjuk kepada mandataris yang dianggap perlu. Pemberi mandat bertanggung jawab sepenuhnya atas keputusan yang diambil berdasarkan mandat, sehingga secara yuridis formal bahwa mandataris pada dasarnya bukan orang lain dari mandat. Selain kepada pegawai bawahan, mandat dapat juga diberikan kepada organ atau pegawai bawahan sesuai ketentuan hukum yang mengaturnya. ${ }^{32}$

Terkait dengan kewenangan seseorang dalam menjalankan jabatannya, maka kewenangan tersebut selalu diikuti dengan pertanggungjawaban setelah menjalankan kewenangan. Berdasarkan ilmu hukum perdata, dasar pertanggungjawaban dibagi menjadi dua macam, yaitu kesalahan dan risiko. Dengan demikian, dikenal dengan pertanggungjawaban atas dasar kesalahan (lilability without based on fault) dan pertanggungjawaban tanpa kesalahan yang dikenal (lilability without fault) yang dikenal dengan tanggung jawab risiko atau tanggung jawab mutlak (strick liabiliy). ${ }^{33}$ Prinsip dasar pertanggungjawaban atas dasar kesalahan mengandung arti bahwa seseorang harus bertanggung jawab karena melakukan kesalahan yang merugikan orang lain,

\footnotetext{
Ibid.

Ibid., hlm. 106.

Ibid.

Ibid., hlm. 107.

Ibid., hlm. 49.
} 
sedangkan prinsip dasar tanggung jawab risiko adalah kewajiban yang timbul akibat risiko dari jabatan atau kedudukan, walaupun risiko tersebut timbul karena suatu perbuatan dilakukan oleh orang lain yang di bawah pegawasannya.

Menurut Muhammad, teori tanggung jawab dalam perbuatan melanggar hukum (tort liability) dibagi menjadi beberapa teori. Pertama, tanggung jawab akibat perbuatan melanggar hukum yang dilakukan dengan sengaja (intertional tort liability), tergugat harus sudah melakukan perbuatan sedemikian rupa sehingga merugikan penggugat atau mengetahui bahwa apa yang dilakukan tergugat akan mengakibatkan kerugian. Kedua, tanggung jawab akibat perbuatan melanggar hukum yang dilakukan karena kelalaian (negligence tort lilability), didasarkan pada konsep kesalahan (concept of fault) yang berkaitan dengan moral dan hukum yang sudah bercampur (interminglend). Ketiga, tanggung jawab mutlak akibat perbuatan melanggar hukum tanpa mempersoalkan kesalahan (stirck liability), didasarkan pada perbuatannya baik secara sengaja maupun tidak sengaja, artinya meskipun bukan kesalahannya tetap bertanggung jawab atas kerugian yang timbul akibat perbuatannya. ${ }^{34}$

Apabila seseorang dirugikan karena perbuatan seseorang lain, sedang di antara mereka itu tidak terdapat sesuatu perjanjian (hubungan hukum perjanjian), maka berdasarkan undang-undang juga terjadi hubungan hukum antara orang tersebut yang menimbulkan kerugian itu. ${ }^{35}$ Hal tersebut diatur dalam Pasal 1365 Kitab UndangUndang Hukum Perdata (KUHPerdata), bahwa tiap perbuatan melanggar hukum yang membawa kerugian pada orang lain, mewajibkan orang yang karena salahnya menerbitkan kerugian itu, mengganti kerugian tersebut.

Menurut Pasal 1365 KUHPerdata, yang dimaksud dengan perbuatan melanggar hukum adalah perbuatan melawan hukum yang dilakukan oleh seseorang karena salahnya telah menimbulkan kerugian bagi orang lain. Dalam ilmu hukum dikenal tiga kategori perbuatan melawan hukum, yaitu perbuatan melawan hukum karena kesengajaan, perbuatan melawan hukum tanpa kesalahan (tanpa unsur kesengajaan maupun kelalaian), dan perbuatan melawan hukum karena kelalaian ${ }^{36}$

Menurut Kelsen, terdapat empat macam pertanggungjawaban hukum, diantaranya pertanggungjawaban individu yaitu seseorang bertanggung jawab terhadap pelanggaran yang dilakukannya sendiri, pertanggungjawaban kolektif berarti bahwa seseorang bertanggung jawab atas suatu pelanggaran yang dilakukan oleh orang lain, pertanggungjawaban berdasarkan kesalahan yang berarti bahwa seseorang bertanggung jawab atas pelanggaran yang dilakukannya karena sengaja dan diperkirakan dengan tujuan menimbulkan kerugian dan pertanggungjawaban mutlak

\footnotetext{
34 Abdulkadir Muhammad. 2010. Hukum Perusahaan Indonesia. Bandung, Citra Aditya Bakti, hlm. 503.

35 A.Z. Nasution. 2002. Hukum Perlindungan Konsumen. Cetakan Kedua. Jakarta: Diapit Media, hlm. 77.

36 Munir Fuady. 2002. Perbuatan Melawan Hukum. Cetakan Kesatu. Citra Aditya Bakti: Bandung, hlm. 3.
} 
yang berarti bahwa seseorang bertanggung jawab atas pelanggaran yang dilakukannya karena tidak sengaja dan tidak diperkirakan. ${ }^{37}$

Selanjutnya Shidarta menjelaskan bahwa secara umum prinsip-prinsip tanggung jawab dalam hukum dapat dibedakan sebagai berikut. Pertama, prinsip tanggung jawab berdasarkan unsur kesalahan. Kedua, prinsip praduga untuk selalu bertanggung jawab. Ketiga, prinsip praduga untuk tidak selalu bertanggung jawab. Keempat, prinsip tanggung jawab mutlak. Kelima, prinsip tanggung jawab dengan pembatasan. ${ }^{38}$

Prinsip tanggung jawab berdasarkan unsur kesalahan (fault liability atau liability based on fault) adalah prinsip yang cukup umum berlaku dalam hukum pidana dan perdata. Dalam Pasal 1365, 1366, dan 1367 KUHPerdata, prinsip ini dipegang secara teguh. Prinsip ini menyatakan bahwa seseorang baru dapat dimintakan pertanggungjawabannya secara hukum jika ada unsur kesalahan yang dilakukannya. Pasal 1365 KUH Perdata dikenal sebagai pasal tentang perbuatan melawan hukum, mengharuskan terpenuhinya empat unsur pokok, yaitu adanya perbuatan. adanya unsur kesalahan, adanya kerugian yang diderita, dan adanya hubungan kausalitas antara kesalahan dan kerugian.

Kesalahan adalah unsur yang bertentangan dengan hukum. Pengertian hukum tidak hanya bertentangan dengan undang-undang, tetapi juga kepatutan dan kesusilaan dalam masyarakat. Tanggung jawab atas perbuatan melawan hukum dapat disengaja dan tidak disengaja. Sebagaimana dalam Pasal 1366 KUHPerdata, bahwa setiap orang bertanggung jawab tidak saja untuk kerugian yang disebabkan karena perbuatannya, tetapi juga untuk kerugian yang disebabkan kelalaian atau kurang hatihatinya.

Dikaitkan dengan nilai kepastian hukum, maka pertanggungjawaban hukum didasarkan pada peraturan hukum positif atau peraturan perundang-undangan. Pada umumnya, praktisi hanya melihat pada peraturan perundang-undangan atau melihat dari sumber hukum formil, tetapi undang-undang tidak selamanya sempurna dan tidak mungkin undang-undang itu dapat mengatur segala kebutuhan hukum dalam masyarakat secara tuntas. Adakalanya undang-undang tidak lengkapataupun tidak sempurna.

Dalam prinsip praduga untuk selalu bertanggung jawab mengandung arti bahwa tergugat dianggap selalu bertanggung jawab (presumption of liability principle), sampai ia dapat membuktikan ada pada si tergugat. ${ }^{39}$ Saat ini beban pembuktian terbalik (omkering van bewjislast) masih dapat diterima dengan prinsip praduga untuk selalu bertanggung jawab. Dasar pemikiran dari teori pembalikan beban pembuktian adalah seseorang yang dianggap bersalah, sampai yang bersangkutan dapat membuktikan sebaliknya. Hal ini tentu bertentangan dengan asas hukum praduga tidak bersalah.

37 Hans Kelsen. 2006. Teori Hukum Murni. Terjemahan Raisul Mutaqien. Bandung: Nuansa dan Nusamedia, hlm. 140.

38 Shidarta. 2006. Hukum Perlindungan Konsumen. Edisi Revisi. Jakarta: Gramedia Widiasarana Indonesia, hlm. 73-79.

39 Ibid., hlm. 61. 
Prinsip praduga untuk tidak selalu bertanggung jawab merupakan kebalikan dari prinsip praduga untuk selalu bertanggung jawab. Prinsip praduga untuk tidak selalu bertanggung jawab (presumption of nonliability principle) hanya dikenal dalam lingkup transaksi konsumen yang sangat terbatas, dan pembatasan ini biasanya secara common sense dapat dibenarkan. ${ }^{40}$

Prinsip tanggung jawab mutlak (strict liability) sering diidentikkan dengan prinsip tanggung jawab absolut (absolute liability). Dengan begitu, ada pula para ahli yang membedakan kedua terminologi di atas. ${ }^{41}$ Ada pendapat yang mengatakan, strict liability adalah prinsip tanggung jawab yang menetapkan kesalahan tidak sebagai faktor yang menentukan, tetapi ada pengecualian-pengecualian yang memungkinkan dibebaskan dari tanggung jawab, misalnya dalam keadaan force majure. Sebalikanya, absolute liability adalah prinsip tanggung jawab tanpa kesalahan dan tidak ada pengecualiannya.

Prinsip tanggung jawab dengan pembatasan (limitation of liability principle) biasanya sangat disenangi oleh pelaku usaha untuk dicantumkan sebagai klausula eksonerasi dalam perjanjian standar yang dibuatnya. ${ }^{42}$ Dalam perjanjian, misalnya ditentukan barang yang hilang atau rusak, maka hanya dibatasi ganti kerugiannya sebesar sepuluh kali harga barang.

\section{KEWENANGAN DAN TANGGUNG JAWAB NOTARIS PENGGANTI}

Sesuai dengan penjelasan teori kewenangan di atas, maka kewenangan notaris pengganti merupakan kewenangan delegasi, yaitu wewenang yang bersumber dari pelimpahan suatu organ pemerintahan kepada organ lain dengan dasar peraturan perundang-undangan. Prosedur pelimpahan delegasi dari suatu organ pemerintahan kepada organ lain dengan peraturan perundang-undangan. Tanggung jawab jabatan dan tanggung gugat beralih kepada penerima delegasi, dan pemberi delegasi tidak dapat menggunakan wewenang itu lagi kecuali setelah ada pencabutan dengan berpegang pada asas "contraries actus".

Jabatan umum notaris dibentuk karena kehendak dari negara melalui aturan hukum untuk melayani masyarakat dalam memberikan kepastian dan perlindungan hukum khususnya dalam bidang hukum perdata yang secara khusus diatur dalam UUJN. Dengan demikian, jabatan notaris dapat dikatakan sebagai salah satu organ negara atau alat perlengkapan negara yang menjalankan sebagian fungsi negara dalam melayani masyarakat umum, dan dengan kewenangan yang ada padanya sebagaimana ditentukan dalam Pasal 15 UUJN. Kewajiban dan larangannya diatur dalam Pasal 16 dan Pasal 17 UUJN.

Berdasarkan Pasal 27 ayat (1) UUJN ditentukan bahwa Notaris dapat mengajukan permohonan cuti secara tertulis disertai usulan penunjukan notaris

\footnotetext{
40 Ibid.

41 Ibid., hlm. 61.

42 Ibid., hlm. 65 .
} 
pengganti. Berdasarkan Pasal 34 ayat (1) UUJN ditentukan bahwa apabila dalam satu wilayah jabatan hanya terdapat satu notaris, Majelis Pengawas Daerah (MPD) dapat menunjuk notaris pengganti khusus yang berwenang untuk membuat akta untuk kepentingan pribadi notaris tersebut atau keluarganya. Berdasarkan Pasal 35 ayat (1) dan (2) UUJN, jika notaris meninggal dunia, suami/istri atau keluarga sedarah dalam garis lurus keturunan semenda dua wajib memberitahukan kepada MPD, dan jika notaris meninggal dunia pada saat menjalankan cuti, tugas jabatan notaris dijalankan oleh notaris pengganti sebagai pejabat sementara notaris paling lama 30 hari terhitung sejak tanggal notaris meninggal dunia. Sesuai dengan ketentuan ini, maka orang lain yang dapat mempunyai kewenangan delegasi hanyalah notaris pengganti, karena kewenangan yang diberikan kepadanya langsung dari notaris berdasarkan UUJN dan ditetapkan oleh MPD, bukan pejabat sementara notaris dan notaris pengganti khusus. Hal ini dikarenakan kewenangan yang diberikan kepadanya tidak secara langsung dari orang yang mempunyai wewenang sah atas dasar undang-undang, melainkan oleh MPD sebagaimana ditentukan dalam Pasal 34 dan Pasal 35 UUJN.

Mengingat dalam UUJN ditentukan bahwa kewenangan MPD bukan membuat akta, melainkan melakukan pengawasan terhadap pelaksanaan tugas jabatan notaris dengan kewenangannya sebagaimana dalam Pasal 70 UUJN, jika dikatakan kewenangan pejabat sementara notaris dan notaris pengganti khusus sebagai kewenangan yang dilimpahkan dengan proses delegasi maka pejabat sementara notaris dan notaris pengganti khusus dalam menjalankan kewenangannya bukan untuk membuat akta, melainkan untuk melakukan pengawasan dengan kewenangan sebagaimana ditentukan dalam Pasal 70 UUJN.

Seorang notaris dapat mengangkat seorang notaris pengganti, dengan ketentuan tidak kehilangan kewenangannya dalam menjalankan tugas jabatannya. Notaris menyerahkan kewenangannya kepada notaris pengganti, apabila sedang cuti, sakit atau berhalangan sementara, yang setelah cuti habis protokolnya dapat diserahkan kembali kepada notaris yang digantikannya. Pelimpahan wewenang kepada notaris pengganti didelegasikan langsung dari yang mempunyai wewenang, yaitu untuk notaris yang melakukan cuti, notaris tersebut wajib menunjuk notaris pengganti. Usulan penunjukan notaris pengganti dilakukan bersamaan dengan permohonan cuti secara tertulis.

Pertanggungjawaban notaris pengganti dapat diminta apabila masih berwenang dalam melaksanakan tugas jabatan sebagai notaris, atau kesalahan-kesalahan yang dilakukan dalam menjalankan tugas jabatan notaris dan sanksi-sanksi yang dapat dikenakan terhadap notaris dapat dijatuhkan selama notaris pengganti masih berwenang untuk melaksanakan tugas jabatan sebagai notaris. Berdasarkan Pasal 32 ayat (2) UUJN, menyatakan bahwa notaris pengganti menyerahkan protokol notaris kepada notaris setelah cuti berakhir. Dengan demikian, dapat diketahui bahwa notaris dapat menggunakan wewenang yang didelegasikannya kepada notaris pengganti setelah masa cutinya berakhir, karena ketentuan yang mengatur mengenai notaris 
pengganti adalah untuk menjaga kesinambungan jabatan notaris dalam melayani masyarakat, khususnya terkait dengan masalah pembuatan akta.

Berdasarkan Pasal 65 UUJN, maka notaris pengganti memiliki tanggung jawab yang sama dengan notaris dalam pembuatan akta autentik. Fungsi yang dimiliki oleh notaris pengganti tidak ada perbedaan dalam hal kewenangan dan tanggung jawab terkait fungsinya sebagai notaris, karena berdasarkan Pasal 33 ayat (2) UUJN, notaris pengganti hanya menggantikan notaris selama notaris tersebut berhalangan.

Tanggung jawab notaris pengganti atas akta yang dibuatnya setelah selesai masa jabatan ataupun masih menjabat sebagai notaris pengganti, sepenuhnya berada pada notaris pengganti, karena notaris pengganti adalah pejabat yang mandiri. Tanggung jawab notaris sebagai profesi lahir dari adanya kewajiban dan kewenangan yang diberikan. Kewajiban dan kewenangan tersebut secara sah dan terikat mulai berlaku sejak notaris pengganti mengucapkan sumpah jabatannya sebagai notaris pengganti. Sumpah yang telah diucapkan tersebutlah yang seharusnya mengontrol segala tindakan notaris pengganti dalam menjalankan jabatannya.

Penerapan sanksi terhadap notaris juga merupakan bentuk pertanggungjawaban notaris pengganti dalam menjalankan fungsinya sebagai pembuat akta. Ada dua istilah yang merujuk pada pertanggungjawaban dalam kamus hukum, yakni liability dan responsibility. Liability ialah dalam pengertian dan penggunaan praktis merujuk pada pertanggungjawaban hukum. Seseorang yang bertanggung jawab secara hukum atas perbuatannya bahwa dia dapat dikenai sanksi karena perbuatannya melawan hukum. Istilah hukum yang luas yang merujuk hampir semua karakter risiko atau tanggung jawab, yang pasti, yang bergantung atau yang meliputi semua karakter hak dan kewajiban secara aktual atau potensial seperti kejahatan, kerugian, ancaman, biaya atau kondisi yang menciptakan tugas untuk melaksanakan undang-undang. Responsibility yaitu suatu hal yang harus dipertanggungjawabkan terhadap kewajiban, termasuk putusan, keterampilan dan kecakapan yang juga meliputi ketaatan dan kepatuhan bertanggung jawab atas undang-undang yang dilaksanakan. Pengertian praktis dari istilah liability menunjuk pada suatu pertanggungjawaban hukum, yakni tanggung gugat akibat kekeliruan yang diperbuat subjek hukum, sedangkan responsibility menunjuk pada pertanggungjawaban politik. ${ }^{43}$

Mengenai pertanggungjawaban pejabat menurut Kranenburg dan Vegtig sebagaimana dikutip Ridwan H.R., bahwa ada dua teori yang melandasinya. Pertama, teori fautes personalles, ialah teori yang menyatakan bahwa kerugian pihak ketiga itu dibebankan kepada pejabat yang akibat dari perbuatannya menimbulkan kerugian. Di dalam teori ini beban tanggung jawab ditujukan kepada manusia selaku pribadi. Kedua, teori fautes de service, ialah teori yang mengatakan bahwa kerugian kepada pihak ketiga ditujukan atau dibebankan kepada instansi atau badan dari tempat pejabat tersebut berasal. Penjelasan di dalam teori ini tanggung jawab dibebankan kepada jabatannya.

43 Ridwan H.R. supra note 19, hlm. 335-337. 
Pelaksanaan dalam menentukan tanggung jawab harus melihat seberapa besar kesalahan yang dilakukan oleh pejabat tersebut, karena besar dan kecilnya suatu kesalahan berdampak pula kepada pertanggungjawaban yang harus ditanggungnya. ${ }^{44}$

Prinsip pertanggungjawaban berdasarkan besar dan kecilnya suatu kesalahan dijadikan sebagai landasan untuh menjatuhkan sanksi kepada notaris. Pertanggungjawaban berdasarkan unsur kesalahan (fault liability atau liability based on fault) ialah prinsip yang biasa digunakan hukum perdata, khususnya di dalam Pasal 1365, 1366, dan 1367 KUHPerdata. Prinsip ini menjelaskan bahwa seseorang dapat dimintai pertanggungjawaban secara hukum, jika terdapat kesalahan yang dilakukan olehnya. Pasal 1365 KUHPerdata menjelaskan tentang perbuatan melawan hukum, di dalam pasal ini mengharuskan adanya empat unsur pokok kesalahan, yaitu adanya suatu perbuatan melawan hukum, adanya suatu unsur kesalahan, adanya suatu kerugian yang diderita, dan adanya suatu hubungan kausalitas antara kesalahan dan kerugian. Kesalahan adalah unsur yang bertentangan dengan hukum atau pelanggaran hukum. Pelanggaran hukum tidak hanya bertentangan dengan undang-undang, tetapi juga bertentangan dengan kepatutan dan kesusilaan.

Terkait dengan teori tanggung jawab, bahwa pertanggungjawaban yang dilakukan oleh notaris pengganti merupakan akibat pelaksanaan tugas dan jabatannya. Oleh karena itu, tanggung jawab yang digunakan dalam UUJN adalah tanggung jawab berdasarkan kesalahan. Notaris dapat dimintakan pertanggungjawaban apabila terdapat unsur kesalahan yang dilakukannya. Perlu diadakannya pembuktian terhadap unsur-unsur kesalahan yang dibuat notaris tersebut, yang meliputi hari, tanggal, bulan, dan tahun menghadap; waktu menghadap; dan tanda tangan yang tercantum dalam minuta akta. ${ }^{45}$

\section{KESIMPULAN}

Kewenangan notaris pengganti merupakan kewenangan delegasi, yaitu wewenang yang bersumber dari pelimpahan suatu organ pemerintahan kepada organ lain dengan dasar peraturan perundang-undangan. Prosedur pelimpahan delegasi dari suatu organ pemerintahan kepada organ lain dengan peraturan perundang-undangan. Tanggung jawab jabatan dan tanggung gugat beralih kepada penerima delegasi, dan pemberi delegasi tidak dapat menggunakan wewenang itu lagi kecuali setelah ada pencabutan dengan berpegang pada asas "contraries actus".

Tanggung jawab notaris pengganti atas akta yang dibuatnya setelah selesai masa jabatan ataupun masih menjabat sebagai notaris pengganti, sepenuhnya berada pada notaris pengganti, karena notaris pengganti ialah pejabat yang mandiri. Terkait dengan teori tanggung jawab, bahwa pertanggungjawaban yang dilakukan oleh notaris

44 Ibid., hlm. 205.

45 Habib Adjie. 2009. Meneropong Khasanah Notaris dan PPAT Indonesia. Bandung: Citra Aditya Bakti, hlm. 192. 
pengganti merupakan akibat pelaksanaan tugas dan jabatannya. Tanggung jawab yang digunakan dalam UUJN adalah tanggung jawab berdasarkan kesalahan, sehingga notaris pengganti dapat dimintakan pertanggungjawaban, jika terdapat unsur kesalahan yang dilakukan.

\section{DAFTAR PUSTAKA}

Abdul Ghofur Anshori. 2009. Lembaga Kenotariatan Indonesia, Perspektif Hukum dan Etika, Yogyakarta: UII-Press.

Abdul Rasyid Thalib. 2006. Wewenang Mahkamah Konstitusi dan Aplikasinya dalam Sistem Ketatanegaraan Republik Indonesia. Bandung: Citra Aditya Bakti

Abdulkadir Muhammad. 2010. Hukum Perusahaan Indonesia. Bandung, Citra Aditya Bakti. Agussalim. 2007. Pemerintahan Daerah Kajian Politik dan Hukum. Bogor: Ghalia Indonesia. Ateng Syafrudin. 2000. "Menuju Penyelenggaraan Pemerintahan Negara yang Bersih dan Bertanggungjawab". Jurnal Pro Justisia. Edisi IV. Bandung: Universitas Parahyangan.

Bambang Sunggono. 1998. Metodologi Penelitian Hukum. Cetakan Kedua. Jakarta: Raja Grafindo Persada.

Gunawan Setiardja, A. 1990. Dialektika Hukum dan Moral dalam Pembangunan Masyarakat Indonesia. Yogyakarta: Kanisius.

Herlien Budiono. 2013. Kumpulan Tulisan Hukum Perdata di Bidang Kenotariatan Buku Kedua. Bandung: Citra Aditya Bakti.

Husni Thamrin. 2011. Pembuatan Akta Pertanahan oleh Notaris. Yogyakarta: Pressindo.

Johny Ibrahim. 2006. Teori \& Metodologi Penelitian Hukum Normatif. Cetakan Kedua. Malang: Bayumedia Publishing.

Kelsen, Hans. 2006. Teori Hukum Murni. Terjemahan Raisul Mutaqien. Bandung: Nuansa dan Nusamedia.

Miriam Budiardjo. 1998. Dasar-dasar Ilmu Politik. Jakarta: Gramedia Pustaka Utama.

Munir Fuady. 2002. Perbuatan Melawan Hukum. Cetakan Kesatu. Citra Aditya Bakti: Bandung.

Nasution, A.Z. 2002. Hukum Perlindungan Konsumen. Cetakan Kedua. Jakarta: Diapit Media.

Nico. 2003. Tanggungjawab Notaris Selaku Pejabat Umum. Yogyakarta: Center for Documentation and Studies of Bussines Law.

Paulus Efendie Lotulung. 1994. Himpunan Makalah Asas-asas Umum Pemerintahan yang Baik. Bandung: Citra Aditya Bakti.

Republik Indonesia, Undang-undang Nomor 2 Tahun 2014 tentang Perubahan atas Undang-Undang Nomor 30 tahun 2004 tentang Jabatan Notaris.

Ridwan H.R. 2013. Hukum Administrasi Negara. Jakarta: RajaGrafindo Persada. 
Ronny Hanitijo Soemitro. 1990. Metode Penelitian Hukum dan Jurimetri. Cetakan Keempat. Jakarta: Ghalia Indonesia.

Rusadi Kantaprawira. 1998. Hukum dan Kekuasaan. Yogyakarta: Universitas Islam Indonesia.

Salim, H. dan H. Abdulah. 2007. Perancang Kontrak dan MOU. Jakarta: Sinar Grafika.

Shidarta. 2006. Hukum Perlindungan Konsumen. Edisi Revisi. Jakarta: Gramedia Widiasarana Indonesia.

Soegondo Notodisoerjo, R. 1982. Hukum Notariat di Indonesia, Suatu Penjelasan. Jakarta: Rajawali Pers.

Soegondo Notodisoerjo, R. 1993. Hukum Notariat di Indonesia. Jakarta: Raja Grafindo.

Soerjono Soekanto dan Sri Mamudji. 2003. Penelitian Hukum Normatif, Suatu Tinjauan Singkat. Cetakan Keenam. Jakarta: RadaGrafindo Persada

Soerjono Soekanto. 1986. Pengantar Penelitian Hukum, Jakarta: Penerbit Universitas Indonesia.

Subekti, R. 1996. Pokok-pokok Hukum Perdata. Jakarta: Intermasa.

Sudikno Mertokusumo. 1998. Hukum Acara Perdata Indonesia. Yogyakarta: Liberty.

Suwoto Mulyosudarmo. 1990. Kekuasaan dan Tanggung Jawab Presiden Republik Indonesia, Suatu Penelitian Segi-segi Teoritik dan Yuridis Pertanggungjawaban Kekuasaan. Surabaya: Universitas Airlangga.

Tengku Erwinsyahbana dan Ramlan. 2017. "Penelitian Kualitatif Bidang Ilmu Hukum dalam Perspektif Filsafat Konstruktivis". Jurnal Borneo Law Review. Volume 1 Issue 1. Juni.

Tengku Erwinsyahbana. 2017. "Pertanggungjawaban Yuridis Direksi terhadap Risiko Kerugian Keuangan Daerah pada Badan Usaha Milik Daerah”. Jurnal Ilmu Hukum De Lega Lata. Volume 2 Nomor 1. Januari-Juni. 
340 | Kewenangan dan Tanggung Jawab Notaris Pengganti setelah Pelaksanaan Tugas dan Jabatan Berakhir

This page is intentionally left blank 